\title{
Protein concentrates from defatted rice bran: preparation and characterization
}

\author{
Inajara Beatriz Brose PIOTROWICZ ${ }^{1}$, Myriam Mercedes SALAS-MELLADO ${ }^{1 *}$
}

\begin{abstract}
The goal of this work is to determine the optimal conditions for the obtaining of protein concentrates from rice bran. The effects of defatting processes applied to this product in laboratory and in industrial scales were investigated. Through two experimental designs were performed, and production conditions to obtain the protein concentrates were chosen with values of protein contents average $59.9 \%$ and $57.1 \%$, with protein yields of $61.6 \%$ and $30.7 \%$. The concentrates produced with industrially defatted rice bran showed higher digestibility and increased thermal stability compared with the product obtained with laboratory defatted rice bran. Both concentrates show molecular weight proteins below $50 \mathrm{kDa}$. The morphology of the precipitated proteins, analyzed by scanning electron microscopy, there was a great difference in the size of particles, which form the wet precipitates. The differences presented by the concentrates can be due to defatting processes which raw materials were submitted. Thus, studying the protein extraction conditions and knowing its characteristics is very important for the industry, because food processing requires knowing the behavior of each compound during and after processes they will be submitted.
\end{abstract}

Keywords: defatted rice bran; extraction conditions; protein concentrates.

Practical Application: Properties of proteins can be changed by industrial process.

\section{Introduction}

Nowadays, the increasing demand for high quality protein constituents increased researching of these constituents. Rice bran is a waste from rice polishing process, accounting for about 8 to $11 \%$ of the grain, and can be a source of protein for the production of concentrates and isolates (Chaud et al., 2009; Parrado et al., 2006). In the state of Rio Grande do Sul (Brazil), just in December 2016, more than 600 thousand tons of rice were processed (Instituto Riograndense do Arroz, 2017). It produced about 66 thousand tons of rice bran (RB), from which the defatted rice bran (DRB) is generated, part is applied for animal feed and the remainder is a waste from rice industry (Generoso et al., 2008; Gomes et al., 2007). The large amount of rice bran generated justify its use as a source of proteins of great nutritional value.

Much research has been done on protein isolation of cereals, legumes, algae, seeds and their byproducts, assessing functional, chemical, physical, thermal and structural properties (Bandyopadhyay et al., 2008; Joshi et al., 2011; Kumar et al., 2014; Hojilla-Evangelista et al., 2014; Zhang et al., 2012). Bandyopadhyay et al. (2008) studied the functional properties of concentrated and hydrolyzed proteins of DRB. However, it is very important to investigate other properties like digestibility, molecular weight, thermal stability, structure and morphology of the protein, knowing the product characteristics against its processing. Zhao et al. (2012) stated that protein denaturation from processed rice endosperm is associated to the differences reported on the resulted protein concentrates. They considered that the denaturation of the proteins from the processed endosperm could be responsible for the differences found in the concentrates, like improved solubility, emulsifying properties, foam capacities, water/oil holding capacity and surface hydrophobicity, compared to the native endosperm protein.

Many industrial processes are able to change food components, including proteins when compared to laboratory process that enables to maintain the structure of the native protein with little changes. Pelleting is one of the processes carried out on rice bran in order to retain the coproduct. This process prevents the action of lipolytic enzymes that degrade lipids, resulting on rancidity. Prabhu et al. (1999) studied extraction, activity and stability of rice bran lipases and verified the thermal stability. The extract was incubated at different temperatures ranging from 10 to $65^{\circ} \mathrm{C}$ for $15 \mathrm{~min}$. It was observed that, up to $40^{\circ} \mathrm{C}$, the loss in activity is negligible. However, incubation at higher temperatures leads to rapid loss of activity. As mentioned by Maragno \& Kuhn (2013), the pelletization process is a technology applied for the preservation of the bran, where an agglomeration of milled particles occurs by mechanical processes, combined with moisture, heat and pressure conditions.

Pelletization process uses reduced values of temperature and pressure, increasing process time, when compared with extrusion. However, the action of heat can denature and disable the protein of $\mathrm{RB}$, when compared with a rice bran defatting in laboratory, without thermic and pressure process, which can influence the quality of proteins. These data would be useful to predict their potential utilization in specific food products and the appropriated industrial processing. In this context, the goal of this work is obtaining and characterization of protein concentrates from rice wastes. The effects of defatting processes 
applied to these products in industry and laboratory scales were investigated.

\section{Materials and methods}

Crude rice bran $(\mathrm{RB})$ was obtained from the rice processing industry and the waste from industry defatted rice bran (DRB) were obtained from Pelotas, Rio Grande do Sul, Brazil. All chemical reagents used in this study were of analytical grade. Hexane (Synth, Diadema, Brazil), sodium hydroxide (Vetec, Rio de Janeiro, Brazil), hydrochloric acid (Dinamica, Diadema, Brazil), acrylamide for electrophoresis (Vetec, Rio de Janeiro, Brazil), Lauryl sulfate sodium salt (Proquimios, Rio de Janeiro, Brazil), Pepsin from hog stomach (Sigma-Aldeich, São Paulo, Brazil), Pancreatin from porcine pancreas (Sigma-Aldrich, São Paulo, Brasil) and Potassium Bromide Fourier transform infrared spectroscopy (FT-IR) grade (Sigma-Aldrich, São Paulo, Brazil)

\subsection{Preparation and composition of the defatted bran}

Rice bran was initially sieved on 42 mesh screen $(0.335 \mathrm{~mm})$ for the removal of husk, grits and other major components. Afterwards, RB was subjected to degreasing according to Wang et al. (1999), with hexane in a 1:3 ratio (w/v) of bran:hexane, while stirring in a shaker (Cientec, CT-712RNT, Brazil) at $50{ }^{\circ} \mathrm{C}$ for 30 minutes. The hexane with fat was removed, making the solvent replacement and more one extraction step was performed, using the same conditions previously described. After the removal of hexane, the wet defatted bran was placed in a large container and the excess of solvent to evaporate at laboratory chapel with exhaust system for 18 hours. This bran was sieved again, but in a 100 mesh sieve $(0.150 \mathrm{~mm})$ to obtain DRB-1 sample.

The defatted bran obtained from the industry (DRB-2) in pellet form, was ground in a Wiley mill (Tecnal, TE-650, Brazil) and sieved in a 100 mesh sieve. The defatted and sieved bran were characterized by proximal composition according to AOAC (Association of Official Analytical Chemists, 2000) and the amount of carbohydrates was determined by difference.

\subsection{Obtaining the defatted rice bran protein concentrate (DRBPC)}

To obtain the concentrates the $\mathrm{pH}$-shift method was used (Nolsoe \& Undeland, 2009), performing protein solubilization of the brans (DRB-1 and DRB -2) at alkaline $\mathrm{pH}(\mathrm{pH} 11.0-\mathrm{NaOH}$ $1 \mathrm{M})$ and precipitation at the isoelectric point of the protein ( $\mathrm{pH} 4.5-1 \mathrm{M} \mathrm{HCl}$ ). After solubilization, the suspension was centrifuged at $8670 \mathrm{xg}$ for 20 minutes at $20^{\circ} \mathrm{C}$, the supernatant was collected, which precipitated after $\mathrm{pH}$ adjustment of 4.5 , being subjected to centrifugation under the same conditions described above. The precipitate was neutralized with water and 1.0 M NaOH, and freeze-dried (LIOTOP L108, Brazil), obtaining the dry DRBPC.

\subsection{Characterization of concentrates}

After evaluating each planning, the best conditions for the obtaining of the concentrates were chosen, these were subjected to other characterization analyses: proximal composition, molecular weight, digestibility, calorimetry, infrared spectroscopy and scanning electron microscopy. The moisture, protein, fat and ashes content of the concentrates were determined by official method of AOAC (Association of Official Analytical Chemists, 2000).

\subsection{Molecular weight}

To determine the molar mass of DRBPC-1 and DRBPC-2 concentrates polyacrylamide gel electrophoresis was performed containing sodium dodecyl sulfate (SDS-PAGE) in a concentration of $14 \%$, according to Laemmli (1970). The concentrate samples $\left(0.4 \%-\mathrm{w}_{\text {protein }} / \mathrm{v}_{\text {water }}\right)$ were treated with $100 \mu \mathrm{L} 5 \% \beta$-mercaptoethanol. The molecular weight of the bands was determined by comparison with a standard containing phosphorylase-b $(97 \mathrm{kDa})$, albumin (66 kDa), Ovalbumin (45 kDa), carbonic anhydrase (30 kDa), trypsin inhibitor $(20.1 \mathrm{kDa})$ and $\alpha$-Lactalbumin $(14.4 \mathrm{kDa})$ (Amersham Low Molecular Weight Calibration Kit for Electrophoresis SDS, GE Healthcare, UK).

\subsection{Digestibility}

To verify the digestibility of the concentrates, the method described by Akeson \& Stahmann (1964) was used with modifications. For this, $1 \mathrm{~g}$ of the concentrate was subjected to an initial hydrolysis with $10 \mathrm{~mL}$ of pepsin at a concentration of $3 \mathrm{mg} / \mathrm{mL}$ for 3 hours at $37^{\circ} \mathrm{C}$. The medium was then neutralized and the hydrolysis performed with $10 \mathrm{~mL}$ of pancreatin at a concentration of $4 \mathrm{mg} / \mathrm{mL}$, for 24 hours at $37^{\circ} \mathrm{C}$. The digested protein content was determined by Kjeldahl ${ }^{\circ} 920.87$ (Association of Official Analytical Chemists, 2000), relating it to the initial amount of protein, subjected to digestion. A blank sample was prepared without addition of the sample, evaluating the protein content of the enzymes.

\subsection{Differential Scanning Calorimetry (DSC)}

'Thermal stability of proteins was evaluated by differential scanning calorimetry (DSC) (DSC-Q20, TA Instruments, New Castle, USA) according to the methodology of Zhang et al. (2012). It were weighed $3 \mathrm{mg}$ of concentrates into aluminum caps, sealed and heated at a rate of $10^{\circ} \mathrm{C} / \mathrm{min}$ in a temperature range from 30 to $200{ }^{\circ} \mathrm{C}$ using an empty capsule as reference. The onset $\left(\mathrm{T}_{\mathrm{o}}\right)$, denaturation $\left(\mathrm{T}_{\mathrm{d}}\right)$ and final $\left(\mathrm{T}_{\mathrm{f}}\right)$ temperatures and the enthalpy of denaturation $(\Delta \mathrm{H})$ were analyzed from the curves obtained using the instrument software.

\subsection{Infrared Spectroscopy (FT-IR)}

In order to evaluate the structure and the compounds present in the concentrates, Fourier transform infrared spectrometry was used in the $4000-400 \mathrm{~cm}^{-1}$ region, and the number of scans of 45 , with a resolution of $4 \mathrm{~cm}^{-1}$ according to Zhao et al. (2012). For this, the diffuse reflectance technique with potassium bromide pellets was used. The spectra were obtained by IRsolution View 1.5 program, (Prestige-21 The-210 045, Shimadzu, Japan), supplied with the equipment. 


\subsection{Scanning Electron Microscopy (SEM)}

A scanning electron microscopy on samples of the precipitate formed in the isoelectric point of the protein $(\mathrm{pH} 4.5)$ was performed after to colect $10 \mu \mathrm{L}$ of the precipitated suspension and placed on the aluminum stub, allowing it to dry in an oven at $25{ }^{\circ} \mathrm{C}$ for 16 hours. For the assay o the microscope (Jeol, JSM - 6610LV, Japan), specimens were coated with a thin layer of gold and an acceleration of $15 \mathrm{kV}$ electrons was used.

\subsection{Statistical analyses}

Two full $2^{3}$ factorial experimental designs were carried out, totalizing 17 trials using DRB- 1 and DRB- 2 brans to obtain the respective DRBPC-1 and DRBPC-2 concentrates. The responses studied were dry concentrate yield $\left(\mathrm{M}_{\mathrm{y}}\right)$, protein content $\left(\mathrm{P}_{\mathrm{c}}\right)$ of dry concentrate (Kjeldahl \%N x 5.95) and protein yield $\left(\mathrm{P}_{\mathrm{y}}\right)$.

For the calculation of $\mathrm{M}_{\mathrm{y}}$ and $\mathrm{P}_{\mathrm{y}}$, Equations 1 and 2 were used, where $m_{\text {conc }}$ is the mass of the dry concentrate, $m_{D R B}$ is the mass of DRB used in the process, $\mathrm{P}_{\text {conc }}$ is the percentage of dry protein concentrate and $\mathrm{P}_{\mathrm{DRB}}$ is the content of protein in the $\mathrm{DRB}$.

$M_{y}=\frac{m_{\text {conc }}}{m_{D R B}} x 100$

$P_{y}=\frac{m_{\text {conc }} x P_{\text {conc }}}{m_{D R B} x P_{D R B}} \times 100$

The response surface methodology (contour surface) was used to analyse the effects of the following parameters: mass yield, protein content and protein yield. The interaction between the variables was evaluated using the software Statistica (Version 7.0, by StatSoft, Inc., Tulsa, USA) using a confidence interval of
95\%. Means were compared by Student's t-test at the $5 \%$ level of significance by analysis of variance (ANOVA).

\section{Results and discussions}

\subsection{Experimental design for the defatted rice bran protein concentrates (DRBPC)}

Table 1 shows the mass yield values, protein content and yield of protein concentrates obtained by different conditions according to the experimental design.

The yield of solid obtained after defatting rice obtained in this work show that DRBP-1 concentrates were higher than DRBPC -2, but the average percentage of protein made up 8.4\% higher in DRBPC-2. It is possible to consider the greater DRBPC-1 mass yield value because of the higher amount of non-protein compounds, so the protein yield is directly linked to mass yield. Despite this, we may considered the potential of this industrial waste as a protein source, which was higher than the $8.8 \%$ reported by Boonla et al. (2015) when worked defatted rice bran protein.

The effects of the variables DRB: $\mathrm{H}_{2} \mathrm{O}$ ratio, temperature and process time in mass yield of the concentrate, on the percentage of protein and the protein yield were verified. In DRBPC- 1 it was found for the responses mass and protein yield only the variable Temperature (linear and quadratic) were significant. For protein content, beside Temperature, the $\mathrm{DRB}: \mathrm{H}_{2} \mathrm{O}$ ratio showed a negative effect, and for DRB: $\mathrm{H}_{2} \mathrm{O}$ with time interactions, the effect was positive. In DRBPC-2 it were verified that the variables applied were most influential on protein yield and protein content. Mass yield and protein yield were significantly influenced by parameters DRB: $\mathrm{H}_{2} \mathrm{O}$ ratio (Quadratic) and Temperature (Linear), with smaller DRB: $\mathrm{H}_{2} \mathrm{O}$ ratio and higher temperature leading to the highest mass and protein yield of concentrate. In the percentage

Table 1. Experimental design of 17 trials with mass yield $\left(\mathrm{M}_{\mathrm{Y}}\right)$, protein content $\left(\mathrm{P}_{\mathrm{C}}\right)$ and protein yield $\left(\mathrm{P}_{\mathrm{Y}}\right)$ value of DRBPC-1 and DRBPC-2 $(\alpha=1.68)$.

\begin{tabular}{|c|c|c|c|c|c|c|c|c|c|}
\hline \multirow{2}{*}{ Trial } & \multirow{2}{*}{$\begin{array}{c}\text { DRB: } \mathrm{H}_{2} \mathrm{O} \\
(\mathrm{g} / \mathrm{mL})\end{array}$} & \multirow{2}{*}{$\mathrm{T}\left({ }^{\circ} \mathrm{C}\right)$} & \multirow{2}{*}{$\mathrm{t}(\min )$} & \multicolumn{3}{|c|}{ DRBPC-1 } & \multicolumn{3}{|c|}{ DRBPC-2 } \\
\hline & & & & $\mathrm{M}_{\mathrm{Y}}$ & $\mathrm{P}_{\mathrm{c}}$ & $\mathrm{P}_{\mathrm{Y}}$ & $\mathrm{M}_{\mathrm{Y}}$ & $\mathrm{P}_{\mathrm{c}}$ & $\mathrm{P}_{\mathrm{Y}}$ \\
\hline 1 & $1: 6$ & 30 & 50 & 12.2 & 59.1 & 51.1 & 2.5 & 69.4 & 11.0 \\
\hline 2 & $1: 8$ & 30 & 50 & 13.2 & 58.0 & 54.3 & 3.2 & 70.4 & 14.3 \\
\hline 3 & $1: 6$ & 50 & 50 & 14.4 & 58.5 & 59.7 & 2.8 & 61.5 & 10.9 \\
\hline 4 & $1: 8$ & 50 & 50 & 14.6 & 58.7 & 60.8 & 3.9 & 64.4 & 15.9 \\
\hline 5 & $1: 6$ & 30 & 70 & 13.4 & 57.5 & 54.6 & 2.3 & 69.0 & 9.9 \\
\hline 6 & $1: 8$ & 30 & 70 & 13.8 & 59.6 & 58.3 & 2.0 & 69.8 & 8.9 \\
\hline 7 & $1: 6$ & 50 & 70 & 14.8 & 53.7 & 56.4 & 4.1 & 64.0 & 16.6 \\
\hline 8 & $1: 8$ & 50 & 70 & 15.2 & 58.5 & 63.1 & 3.3 & 67.0 & 14.0 \\
\hline 9 & $1: 5.3$ & 40 & 60 & 15.0 & 54.5 & 58.0 & 2.4 & 63.9 & 9.7 \\
\hline 10 & $1: 8.7$ & 40 & 60 & 14.4 & 55.6 & 56.8 & 2.8 & 67.6 & 12.0 \\
\hline 11 & $1: 7$ & 23.2 & 60 & 11.2 & 57.4 & 45.8 & 1.7 & 68.2 & 7.3 \\
\hline 12 & $1: 7$ & 56.8 & 60 & 14.8 & 55.4 & 58.1 & 8.5 & 57.1 & 30.7 \\
\hline 13 & $1: 7$ & 40 & 43.2 & 14.4 & 57.2 & 58.4 & 4.7 & 68.5 & 20.4 \\
\hline 14 & $1: 7$ & 40 & 76.8 & 13.6 & 60.7 & 58.5 & 4.4 & 64.7 & 18.0 \\
\hline 15 & $1: 7$ & 40 & 60 & 14.4 & 59.3 & 60.3 & 4.9 & 67.5 & 20.9 \\
\hline 16 & $1: 7$ & 40 & 60 & 15.0 & 59.9 & 63.7 & 4.4 & 67.2 & 18.7 \\
\hline 17 & $1: 7$ & 40 & 60 & 14.2 & 60.4 & 60.8 & 4.4 & 66.8 & 18.6 \\
\hline
\end{tabular}

DRBPC-1: defatted rice bran protein concentrate of DRB-1; DRBPC-2: defatted rice bran protein concentrate of DRB-2. 
of protein, the ratio DRB: $\mathrm{H}_{2} \mathrm{O}$ (Linear), Temperature (Linear) and (Quadratic) and the Temperature with time interaction, were the parameters that showed significant influence. In this case, the larger DRB: $\mathrm{H}_{2} \mathrm{O}$ ratio and smaller Temperature, the greater percentage of protein has been found.

Afterwards, the analysis of variance of the significant variables were carried out, with a 95\% confidence level. In DRBPC-1, the value of Fcal (5.1) was close to Ftab (3.8) and the regression coefficient proved to be low $(\mathrm{R}=0.7383)$. According to Kalil et al. (2000), a model has statistical significance when the Fcal is at least 3 to 5 times greater than the Ftab, thus considering that the model was not predictive for the correlation coefficient. However, for DRBPC-2, it was observed that for the yields $\left(\mathrm{M}_{\mathrm{y}}\right.$ and $\left.\mathrm{P}_{\mathrm{y}}\right)$ the Fcal (13.92 and 13.03) and Ftab (3.74 and 3.74) ratios were similar and three times greater, with a correlation coefficient higher than $80 \%(\mathrm{R}=0.8157$ and $\mathrm{R}=0.8095)$. The percentage of protein, Fcal (17.06) and Ftab (3.26) ratio was five times greater, with a coefficient of $92 \%$. In this case, it was considered a significant and predictive model. From the mathematical models obtained, Equation 3 for mass yields $\left(\mathrm{M}_{\mathrm{y}}\right)$, Equation 4 for protein content $\left(\mathrm{P}_{\mathrm{c}}\right)$ and, Equation 5 for protein yield $\left(\mathrm{P}_{\mathrm{y}}\right)$ of DRBPC-2, it was possible to construct the response surfaces and contour diagrams (Figure 1).

$$
M_{y}=4.64-1.858\left[D R B: \mathrm{H}_{2} \mathrm{O}\right]^{2}+2.27[T]
$$

$P_{c}=67.03+2.04\left[D R B: H_{2} O\right]-5.91\left[D R B: H_{2} O\right]^{2}-2.12[T]^{2}+1.52[T x t]$

$P_{y}=19.63\left[D R B: \mathrm{H}_{2} \mathrm{O}\right]^{2}+7.71[\mathrm{~T}]$
Were, $M_{y}$ is the mass yield, $P_{c}$ is the protein content, $P_{y}$ is the protein yield, DRB: $\mathrm{H}_{2} \mathrm{O}$ is the $\mathrm{DRB}$ and water ratio, $\mathrm{T}$ is the process temperature and $t$ is the solubilization time.

As previously mentioned, the behavior of both yields was similar regarding the process conditions and the protein yield response was dependent on the mass yield. The best yields were obtained in a central condition of the DRB: $\mathrm{H}_{2} \mathrm{O}$ ratio and higher temperature values. This may be possible because of increased solubility of the components present in the bran. Furthermore, to obtain a pure concentrate with higher protein content, it would be necessary to use lower temperatures during the process.

To proceed with this research, it was choose two treatments: for DRBPC-1, assays 14-17 were the ones which stood out in the protein content. In this case, it was considered that the concentrate obtained at the midpoint of the conditions would be ideal to be characterized later, which showed an average protein percentage of 59.9\%; For DRBPC-2, was considered the protein yield the most important variable, thus using the concentrate obtained in Assay 12.

\section{Proximal composition of $D R B$ and $D R B P C$}

Table 2 presents the values of the proximal composition of the defatted rice bran $(0,150 \mathrm{~mm})$ and the two defatted rice bran protein concentrate (DRBPC-1 and DRBPC-2).

The components of DRB-1 and DRB-2 showing significant difference between them. As cited by Pestana et al. (2008), the chemical characteristics of the rice bran depend on factors such as cultivar, grain treatments before the processing, processing system used and the degree of grinding to which the grain is subjected. Due to this, the values expressed in the literature for the rice bran composition varied.
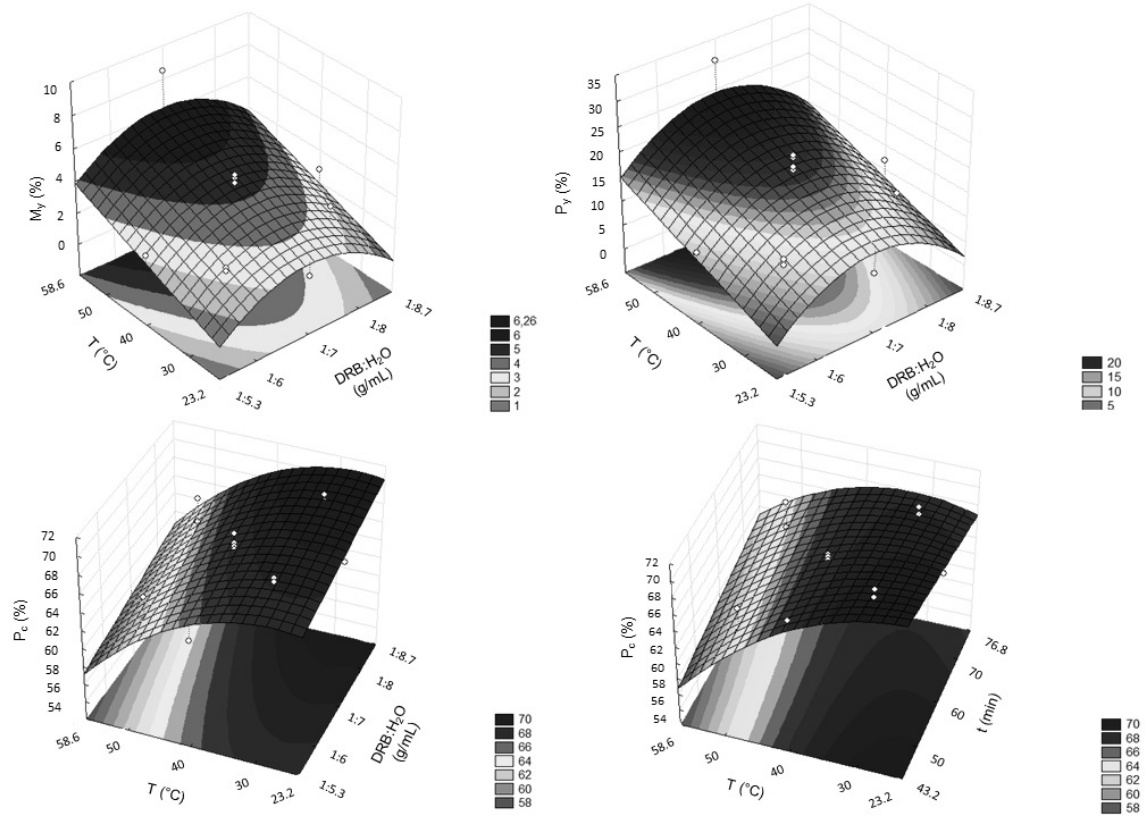

Figure 1. Response surface and contour diagrams of mass yield (My), protein yield (Py) and protein content (Pc) as function of DRB: $\mathrm{H}_{2} \mathrm{O}$, temperature $(\mathrm{T})$ and time $(\mathrm{t})$. 
Table 2. Proximal composition (dry basis) of DRB and DRBPC.

\begin{tabular}{ccccc}
\hline & DRB-1 & DRB- & DRBPC-1 & DRBPC-2 \\
\hline Moisture & $14.6^{\mathrm{a}} \pm 0.3$ & $12.0^{\mathrm{b}} \pm 0.1$ & $3.9^{\mathrm{b}} \pm 0.1$ & $5.4^{\mathrm{a}} \pm 0.1$ \\
Protein & $16.7^{\mathrm{b}} \pm 0.5$ & $17.9^{\mathrm{a}} \pm 0.1$ & $64^{\mathrm{a}} \pm 1$ & $62.1^{\mathrm{a}} \pm 0.4$ \\
Ash & $13.7^{\mathrm{b}} \pm 0.1$ & $16.5^{\mathrm{a}} \pm 0.1$ & $4.3^{\mathrm{b}} \pm 0.1$ & $5.4^{\mathrm{a}} \pm 0.1$ \\
Fat & $5.5^{\mathrm{b}} \pm 0.2$ & $7.7^{\mathrm{a}} \pm 0.7$ & $20.2^{\mathrm{a}} \pm 0.3$ & $\mathrm{Nd}$ \\
Fiber & $4.2^{\mathrm{b}} \pm 0.7$ & $7.4^{\mathrm{a}} \pm 0.2$ & $15.1^{\mathrm{b}} \pm 0.3$ & $\mathrm{Nd}$ \\
Carbohydrates & 59.9 & 50.5 & 11.9 & 17.4 \\
\hline
\end{tabular}

DRB-1: defatted rice bran by laboratory process; DRB-2: defatted rice bran by industrial process; DRBPC-1: defatted rice bran protein concentrate of DRB-1; DRBPC-2: defatted rice bran protein concentrate of DRB-2. Nd: Not detected. Mean \pm standard deviation of three determinations. Different letters in the same line indicate significant difference between the brans $(\mathrm{DRB})$ and between concentrates (DRBPC) $(\mathrm{p}<0.05)$.

Another important factor to explain the differences between the components would be the processes from which the brans were submitted to in industry and laboratory. In the industry (DRB-2), a pelleting process in the whole bran was performed to inactivate lipases, using high temperature and pressure. The pelletized bran was ground and sieved $(0.150 \mathrm{~mm})$, causing husk fragments that might be present in the rice bran before being processed to have a reduction in size to the point of passing through the sieve and, therefore resulting in a higher fiber content and ash in the bran. However, the DRB-1 obtained in the laboratory was sieved before being defatted removing a large amount of husks and therefore presented a lower ash content.

Lipid content of DRB by industrial process on a large scale, favors the maintenance a part of lipids in the pelletized bran, unlike the process performed in the laboratory, probably because the quantity of reagents in an industrial scale was not the sameapplied in laboratory, despide of both processes were performed with hexane and at $50{ }^{\circ} \mathrm{C}$.

For characterization analyses of DRBPC larger amount production was conducted in order to achieve a greater quantity of concentrates. Compared with DRB, we observed that the concentrate showed a high protein content, with no significant difference between the concentrates, and with lowering of other components such as ash and carbohydrates, in addition was possible to eliminate fibers in the first centrifugation step. Chandi \& Sogi (2007) worked with three variations of rice to obtaining rice bran protein concentrates with protein content ranged of $52.46 \%$ to $58.92 \%$, studing its functional properties. Bandyopadhyay et al. (2008) produced concentrates from Indian rice bran, with proteins values (86.2\%) higher than this work, but the raw material analyzed in this case had a higher protein content (20.8\%).

It was observed that the content of lipids present in the concentrates was higher compared to the bran. Similar value was verified by Boonla et al. (2015), when working with defatted rice bran and at the end of the process of getting protein, obtained a concentrate with $16.32 \%$ of lipids. This fact can be considered due to the use of higher process temperatures, which allows the lipids to be dragged along with the protein during the precipitation step. The presence of the lipids could be reduced through the use of centrifugation at low temperatures, promoting their separation on the upper phase of the supernatant.

\section{Differential Scanning Calorimetry (DSC) of DRBPC-1 and DRBPC-2}

To check the thermal stability of the concentrates, DSC analysis was performed. The values obtained by the DRBPC-1 and DRBPC-2 DSC curves were, respectively, onset temperatures of 137.74 and $133.19^{\circ} \mathrm{C}$; denaturation temperatures of 144.21 and $140.2^{\circ} \mathrm{C}$; end temperatures of 150.96 and $154.01^{\circ} \mathrm{C}$, showing that the temperatures were close among concentrates. However we noting a greater difference in enthalpy of denaturation, i.e. thermal stability of DRBPC-1 $(38.84 \mathrm{~J} / \mathrm{g})$ was smaller than the DRBPC-2 $(50.69 \mathrm{~J} / \mathrm{g})$. This may be due to the presence of denatured proteins in DRBPC-2. Zhao et al. (2012) also found greater stability of proteins in rice endosperm treated with pressure and temperature, which can result in a compression and aggregation of proteins.

The knowledge of the protein characteristics due to the process temperature variation is related to their thermal stability, when subjected to certain treatments during the elaboration of the food, not causing drastic changes in protein structure and modifications of its properties

\section{Molar mass and digestibility of DRBPC-1 and DRBPC-2}

Figure 2 illustrates the bands corresponding to proteins of DRBPC-1 and DRBPC- 2 concentrates, comparing the molar masses through the bands presented by a standard of known proteins.

The molecular weight of all protein concentrates were less than $50 \mathrm{kDa}$. The DRBPC-1 showed more visible bands compared to the DRBPC-2. This behavior was also observed in protein concentrates from native and heat-treated rice endosperm analyzed by Zhao et al. (2012), where the treated endosperm had reduced visibility bands compared with the concentrate of the native endosperm. The author attributed this difference between the bands to the use of elevated pressure and temperature conditions.

Ellepola et al. (2005) cited a polypeptide known as a-globulin, present in rice, and that has a molecular mass of $26 \mathrm{kDa}$. The bands presented by the concentrates between 20 and $30 \mathrm{kDa}$ bands of a known standard may be due to the presence of this polypeptide, not being very visible in DRBPC - 2 .

The digestibility of DRBPC- 1 was $93.0 \pm 0.2 \%$, significantly differing from DRBPC-2, which was $98.0 \pm 0.4 \%$, i.e. the 


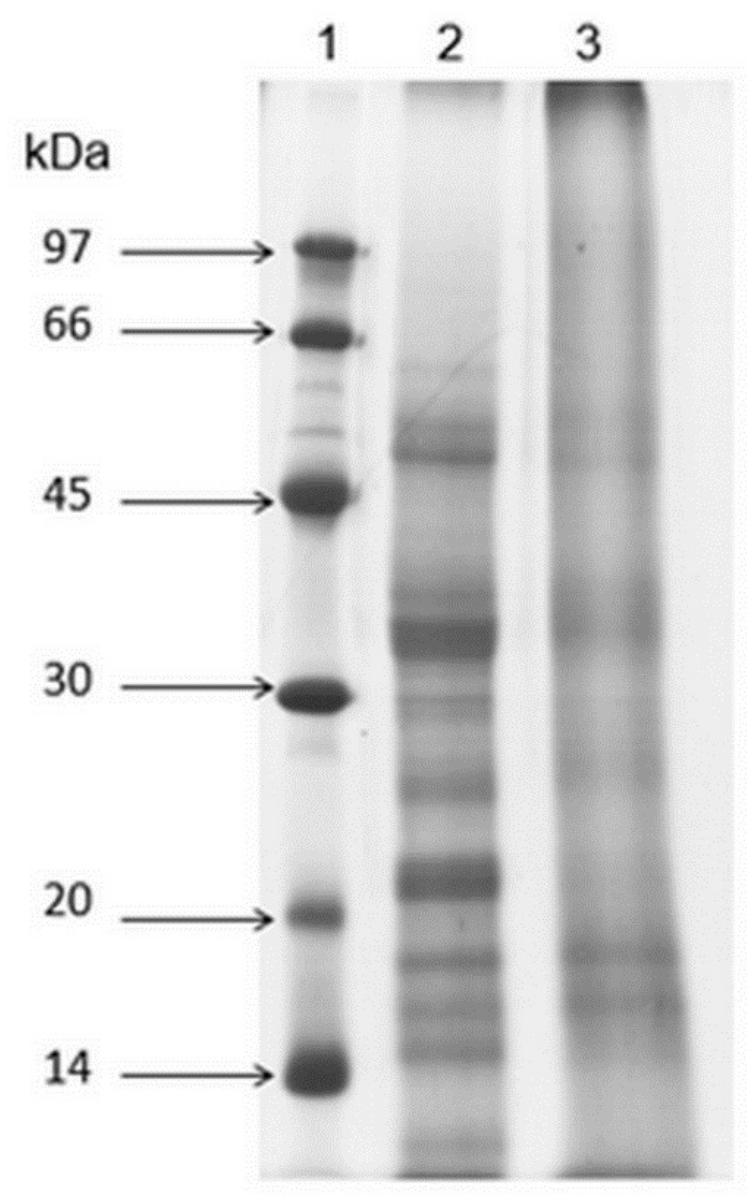

Figure 2. SDS-PAGE profiles of known protein standards (1) and the concentrates DRBPC-1 (2) and DRBPC-2 (3). DRBPC-1: defatted rice bran protein concentrate of DRB-1; DRBPC-2: defatted rice bran protein concentrate of DRB-2.

availability of amino acids in DRBPC-2 would be greater than DRBPC- 1 . The digestibility of rice bran is in the range of $73 \%$, however, when proteins are concentrated they can reach values above 90\% (Saunders, 1990). The separation of the proteins from the other components of the bran and the low molecular weight demonstrated by the electrophoresis facilitated the action of the digestive enzymes, increasing its digestibility. It was also observed that the fact that the amount of digested proteins of DRBPC-2 was higher compared to the DRBPC-1 may be due to the easily digestible denatured proteins presented by DRB-2 due to the industrial process. Naves et al. (2010) also obtained a $27 \%$ increase in the digestibility of pumpkin seeds with and without heat treatment.

\section{Infrared spectrum (FT-IR) of DRBPC-1 and DRBPC-2}

The infrared spectrum permits check the groups and structures that are part of the elemental matrix. Figure 3 shows the infrared spectra of concentrates.
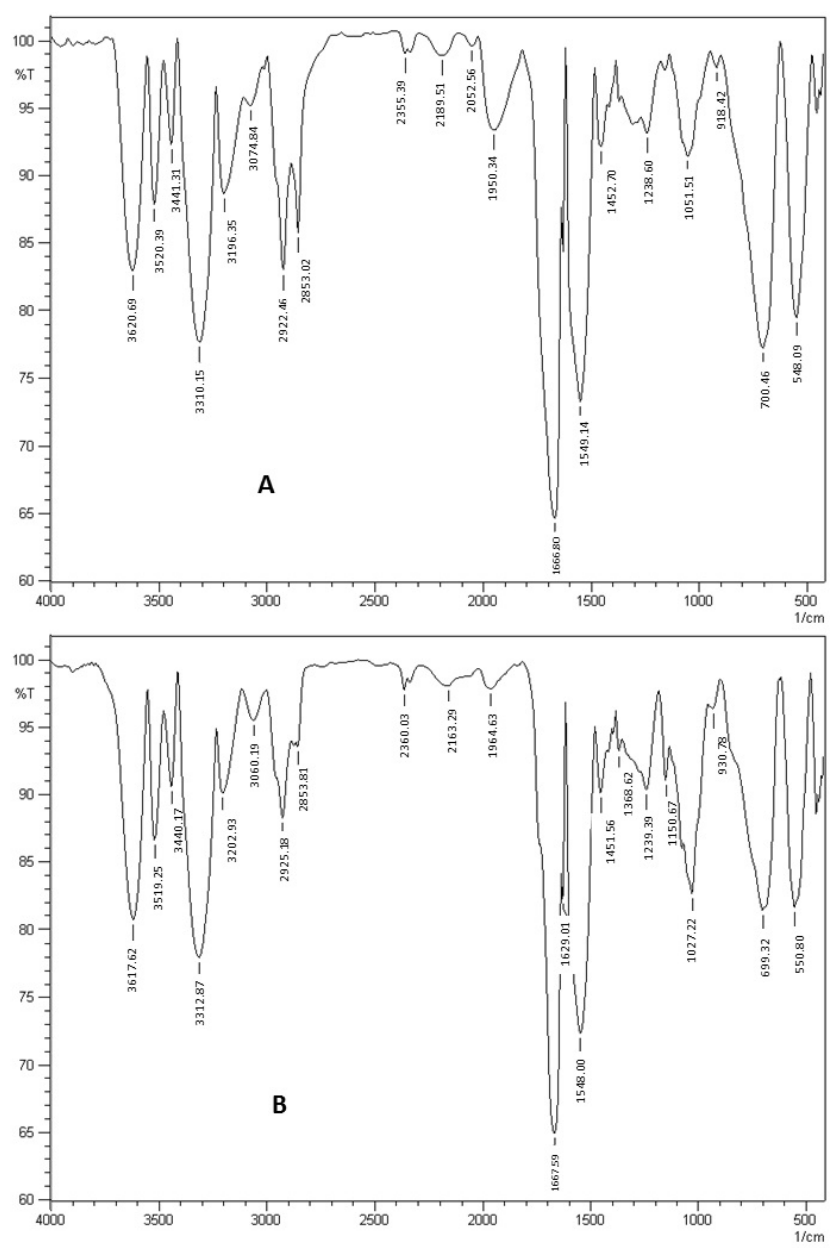

Figure 3. FTIR spectrum of concentrates (A) DRBPC-1 and (B) DRBPC-2. DRBPC-1: defatted rice bran protein concentrate of DRB-1; DRBPC-2: defatted rice bran protein concentrate of DRB-2.

We observed that both spectras were similar and showed that for both samples, the highest peak ranged between 1600 and $1700 \mathrm{~cm}^{-1}$, which are characteristic of the secondary structure of the protein, obtained by the analysis of amide-I band. This band is primarily due to stretching of $\mathrm{C}=\mathrm{O}$ of the peptide bond. As presented by Ellepola et al. (2005), the spectra relating to concentrates, bands obtained by the frequencies of $1666.80 \mathrm{~cm}^{-1}$ (DRBPC-1) and $1667.59 \mathrm{~cm}^{-1}$ (DRBPC-2) are represented by the $\beta$-sheet conformation. The formation of this structure occurs by the reversion of $180^{\circ}$ of polypeptide chain. It comprises a segment of 4 amino acid residues being common to the presence of asparagine, cysteine, glycine, proline and tyrosine, which are folded together and are stabilized by hydrogen bonds (Damodaran et al., 2010). Besides the amide I band, the amide II band, which would refer to the peptide bond is represented by the frequency $1549.14 \mathrm{~cm}^{-1}$ (DRBPC-1) and $1548.00 \mathrm{~cm}-1$ (DRBPC-2).

It was verified the presence of the band $3310.15 \mathrm{~cm}^{-1}$, which may be related to the presence of the starch from the complexation with the protein at the time of precipitation. Carbohydrates such as gums, starch and cellulose consist of polysaccharides 
containing a large amount of $\mathrm{OH}$ groups. The polysaccharides have broad and intense bands near $3300 \mathrm{~cm}^{-1}$ by stretching the $\mathrm{O}-\mathrm{H}$ bond and near $1080 \mathrm{~cm}^{-1}$ by stretching the C-O bond. Bands between $3000-3400 \mathrm{~cm}^{-1}$ are related to the presence of hydroxyls corresponding to polyphenols and alcohols, and in the region of $3600 \mathrm{~cm}^{-1}$ is characteristic for the presence of free hydroxyls (Barbosa, 2007).

\section{Scanning electron microscopy (SEM) of DRBPC-1 and $D R B P C-2$}

The scanning electron microscopy and the aspect of the precipitate formed in the isoelectric point of the protein were observed in Figure 4.

On the plates, precipitates with different aspect were observed where the DRBPC-1 (A) appears in the form of lumps more separated from the aqueous portion compared with the DRBPC-2 (B), which has a more homogeneous appearance.

The structure of a protein is the result of different attractive and repulsive actions relating to the environment they are and changes, such as $\mathrm{pH}$, temperature, ionic strength are able to ensure a conformational readaptation. However, drastic changes in the quaternary, tertiary and secondary structure of the protein

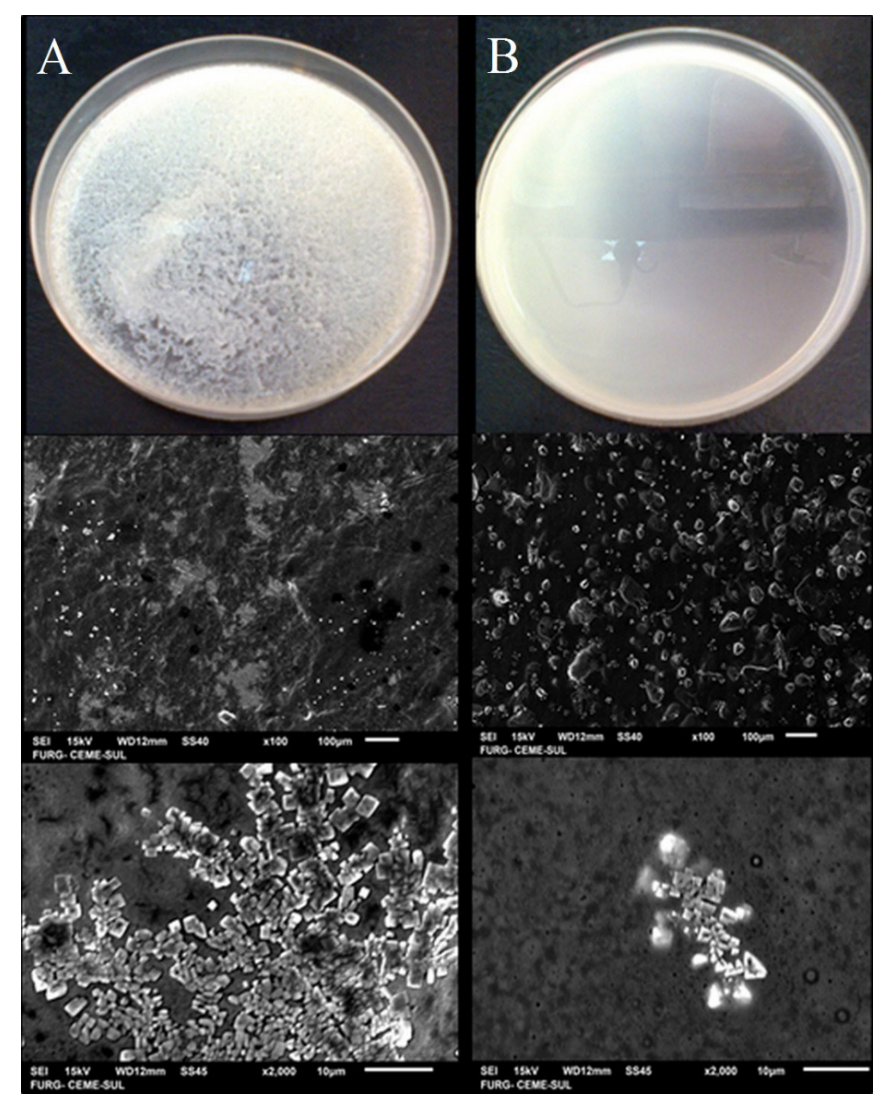

Figure 4. Wet precipitate image and scanning electron microscopy (SEM) micrographs of the dry precipitate surface (A) DRBPC-1 and (B) DRBPC-2 with magnification of $100 \mathrm{x}$ and 2,000 x. DRBPC-1: defatted rice bran protein concentrate of DRB-1; DRBPC-2: defatted rice bran protein concentrate of DRB-2. show that there was protein denaturation (Damodaran et al., 2010). There are no chemical modification of the molecule, but transformation of one molecule in the ordered (native form) for a disordered structure which may result in changes in the way the molecules are grouped when exposed to low $\mathrm{pH}$ values (isoelectric point), obtaining larger or more dispersed structures. The image representation shows that DRB-1 presents a greater complexation of other components during the formation of the protein precipitate, compared to DRB-2. This fact support the results previously presented in the concentrates composition obtained in the experimental design related to protein content.

As a result, protein concentrates obtained under these conditions, can differ in their composition, as well as modified properties, such as digestibility and thermal stability, resulting in distinct products used in food.

\section{Conclusion}

Two protein concentrates were produced from defatted bran rice. It was verified that the protein yield of DRBPC-1 was higher than DRBPC-2 and the temperature influenced positively mass and protein yield but negatively the protein content. The protein concentrates presented some different characteristics in chemical composition, distribution of molar mass, digestibility, thermal stability and aggregation of the proteins, some more pronounced than others, resulting from the industrial stabilization of the bran. Analysing some important properties it can be considered that DRBPC-2 has better properties with regard to availability and digestibility of proteins and a greater thermal stability, can be applied in processes with high temperatures without changing its structure and therefore its physical, chemical and nutritional characteristics.

\section{Acknowledgements}

The authors would like to thank the Irgovel and Josapar industries for providing raw material for this work, and this research was financed by Capes (Coordenação de Aperfeiçoamento de Pessoal de Nível Superior).

\section{References}

Akeson, W. R., \& Stahmann, A. A. (1964). A pepsin pancreatin digest index of protein quality evaluation. The Journal of Nutrition, 83, 257-261. PMid:14191426.

Association of Official Analytical Chemists - AOAC. (2000). Official methods of analysis of Association of Official Analytical Chemists (17th ed.). Gaithersburg: AOAC.

Bandyopadhyay, K., Misra, G., \& Ghosh, S. (2008). Preparation and characterization of protein hydrolysates from indian defatted rice bran meal. Journal of Oleo Science, 57(1), 47-52. PMid:18075222. http://dx.doi.org/10.5650/jos.57.47.

Barbosa, L. C. A. (2007). Espectroscopia no infravermelho: na caracterização de compostos orgânicos (189 p.). Vicosa: Universidade Federal de Viçosa.

Boonla, O., Kukongviriyapan, U., Pakdeechote, P., Kukongviriyapan, V., Pannangpetch, P., \& Thawornchinsombut, S. (2015). Peptidesderived from Thai rice bran improves endothelial function in 
2K-1C renovascular hypertensive rats. Nutrients, 7(7), 5783-5799. PMid:26184305. http://dx.doi.org/10.3390/nu7075252.

Chandi, G. K., \& Sogi, D. S. (2007). Functional properties of rice bran protein concentrates. Journal of Food Engineering, 79(2), 592-597. http://dx.doi.org/10.1016/j.jfoodeng.2006.02.018.

Chaud, L. C. S., Arruda, P. V., \& Felipe, M. G. A. (2009). Potencial do farelo de arroz para utilização em bioprocessos. The Nucleus, 6(2), 33-46. http://dx.doi.org/10.3738/1982.2278.268.

Damodaran, S., Parkin, K. L., \& Fennema, O. R. (2010). Química de alimentos de fennema (4th ed.). Porto Alegre: Artmed Editora.

Ellepola, S. W., Choi, S. M., \& Ma, C. Y. (2005). Conformational study of globulin from rice (Oryza sativa) seeds by Fourier-transform infrared spectroscopy. International Journal of Biological Macromolecules, 37(1-2), 12-20. PMid:16140371. http://dx.doi.org/10.1016/j. ijbiomac.2005.07.008.

Generoso, R. A. R., Gomes, P. C., Rostagno, H. S., Albino, L. F. T., Barreto, S. L. T., \& Brumano, G. (2008). Composição química e energética de alguns alimentos para frangos de corte em duas idades. Revista Brasileira de Zootecnia, 37(7), 1251-1256. http://dx.doi.org/10.1590/ S1516-35982008000700016.

Gomes, J. D. F., Putrino, S. M., Grossklaus, C., Utiyama, C. E., Oetting, L. L., Souza, L. W. O., Fukushima, R. S., Fagundes, A. C. A., Sobral, P. J. A., \& Lima, C. G. (2007). Efeitos do incremento de fibra dietética sobre a digestibilidade, desempenho e características de carcaça: suínos em crescimento e terminação. Semina Ciências Agrárias, 28(3), 483-492. http://dx.doi.org/10.5433/1679-0359.2007v28n3p483.

Hojilla-Evangelista, M. P., Sellinga, G. W., Berhowb, M. A., \& Evangelista, R. L. (2014). Preparation, composition and functional properties of pennycress (Thlaspi arvense L.) seed protein isolates. Industrial Crops and Products, 55, 173-179. http://dx.doi.org/10.1016/j. indcrop.2014.02.016.

Instituto Riograndense do Arroz - IRGA. (2017). CDO - Beneficiamento e saídas de arroz - 2016. Porto Alegre: IRGA. Retrieved from: www. irga.rs.gov.br

Joshi, M., Adhikari, B., Aldred, P., Panozzo, J. F., \& Kasapis, S. (2011). Physicochemical and functional properties of lentil protein isolates prepared by different drying methods. Food Chemistry, 129(4), 1513-1522. http://dx.doi.org/10.1016/j.foodchem.2011.05.131.

Kalil, S., Maugeri, F., \& Rodrigues, M. I. (2000). Response surface analysis and simulation as a tool for bioprocess design and optimization. Process Biochemistry, 35(6), 539-550. http://dx.doi.org/10.1016/ S0032-9592(99)00101-6.

Kumar, K. S., Ganesan, K., Selvaraj, K., \& Subba Rao, P. V. (2014). Studies on the functional properties of protein concentrate of
Kappaphycus alvarezii (Doty) Doty - An edible seaweed. Food Chemistry, 153, 353-360. PMid:24491740. http://dx.doi.org/10.1016/j. foodchem.2013.12.058.

Laemmli, U. K. (1970). Cleavage of structural protein during the assembly of the head of bacteriophage T4. Nature, 227(5259), 680685. PMid:5432063. http://dx.doi.org/10.1038/227680a0.

Maragno, V. P., \& Kuhn, R. C. (2013). Estabilidade do farelo de arroz sob diferentes tratamentos: micro-ondas, peletização e desengorduramento. Ciências Biológicas e da Saúde, 15, 47-53.

Naves, L. P., Corrêa, A. D., Santos, C. D., \& Abreu, C. M. P. (2010). Antinutritional components and protein digestibility in pumpkin seeds (Cucurbita maxima) submitted to different processing methods. Food Science and Technology, 30, 180-184. http://dx.doi.org/10.1590/ S0101-20612010000500027.

Nolsoe, H., \& Undeland, I. (2009). The acid and alkaline solubilization process for the isolation of muscle proteins: state of the art. Food Bioprocess and Technology, 2(1), 1-27. http://dx.doi.org/10.1007/ s11947-008-0088-4.

Parrado, J., Miramontes, E., Jover, M., Gutierrez, J. F., Terán, L. C., \& Bautista, J. (2006). Preparation of a rice bran enzymatic extract with potential use as functional food. Food Chemistry, 98(4), 742-748. http://dx.doi.org/10.1016/j.foodchem.2005.07.016.

Pestana, V. R., Mendonça, C. R. B., \& Zambiazi, R. C. (2008). Farelo de arroz: características, benefícios à saúde e aplicações. Boletim CEPPA, 26, 29-40.

Prabhu, A.V., Tambe, S.P., Gandhi, N.N., Sawant, S.B. and Joshi, J.B. Rice bran lipase: extraction, activity, and stability. Biotechnology Progress, 1999, 15(6), 1083-1089. PMid:10585194. http://dx.doi. org/10.1021/bp990122z.

Saunders, R. M. (1990). The properties of rice bran as a foodstuff. Cereal Foods World, 35, 632-636.

Wang, M., Hettiarachchy, N. S., Qi, M., Burks, W., \& Siebenmorgen, T. (1999). Preparation and functional properties of rice bran protein isolate. Journal of Agricultural and Food Chemistry, 47(2), 411-416. PMid:10563909. http://dx.doi.org/10.1021/jf9806964.

Zhang, H. J., Zhang, H., Wang, L., \& Guo, X. N. (2012). Preparation and functional properties of rice bran proteins from heat-stabilized defatted rice bran. Food Research International, 47(2), 359-363. http://dx.doi.org/10.1016/j.foodres.2011.08.014.

Zhao, Q., Selomulya, C., Xiong, H., Chen, X. D., Ruan, X., Wang, S., Xie, J., Peng, H., Sun, W., \& Zhou, Q. (2012). Comparison of functional and structural properties of native and industrial process-modified proteins from long-grain indica rice. Journal of Cereal Science, 56(3), 568-575. http://dx.doi.org/10.1016/j.jcs.2012.08.012. 